\title{
5,7-Diaryl-3,4,6-trihydronaphthalen-2-ones 의 One-pot 합성
}

\author{
M. Gopalakıishnan*, H. Manikandan. P. Sureshkumar; J. Thanusu, and V. Kanagarajan

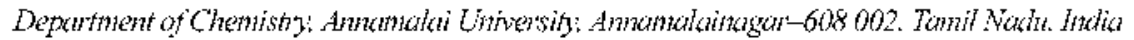 \\ (2007.4.3섭수)
}

\section{One-pot Synthesis of 5,7-Diaryl-3,4,6-trihydronaphthalen-2-ones}

\author{
M. Gopalakuishnan*, H. Manikandan. P. Sureshkumar; J. Thanusu, and V. Kanagarajan \\ Depantment of Chemistry: Amamalai Lniversity: Annamalainagar-608 002. Tamil Nadt. India \\ (Received April 3, 2007)
}

요 약. sodium ethoxide의 존재하에서 3,5-diaryl-cyclohex-2-en-l-one와 methyl vinyl ketone로부터 5,7-Diaryl3,4,6-tribydronaphthalen-2-ones가 합성되었다. 이 생성물은 IR, LV-Visible, 'H-NMR, ${ }^{13} \mathrm{C}-\mathrm{N} M \mathrm{NR}$ 그리고 mass spectral techriques로 구조롤 규병하였다. ' $\mathrm{H}$ 과 ':C signals의 피크늘은은 HSQC spectrum을 끽어 정 확히 규명하였다.

주 제어: 3,5-Diarylcyclohex-2-en-1-ones, Methyl vinyl ketone, Sodium ethoxide, One-pot, 5,7-Diaryl-3,4,6trihydrotnaphthalen-2-ones.

ABSTRACT. 5,7-Diaryl-3,4,6-trihydronaphthalen-2-ones have twen synthesized from 3,5-diaryl-cyclohex-2-en-1ones and methyl vinyl ketone in the presence of sodium ethoxide. The products were characterized by IR, LV-Visible, ${ }^{1} \mathrm{H}-N M R,{ }^{13} \mathrm{C}-N M R$ and mass speetral techniques. To confirm ${ }^{1} \mathrm{H}$ and ${ }^{13} \mathrm{C}$ signals, $\mathrm{H} \$ Q \mathrm{C}$ spectrum was recorded and analyzed.

Keywords: 3,5-Diarylcyclohex-2-en-1-ones, Methyl Vinyl Ketone, Sodium Ethoxide, One-pot, 5,7-Diaryl-3,4,6-trihydronaphthaletr-2-ones

\section{INTRODLCTION}

Michael reaction ${ }^{1}$ is the nucleophilic addition of a carbanion, formed from compounds containing active methylene group to an alpha-beta unsaturated ketone? ester ${ }^{1}$, nitrile, etc. There is a general interest in the synthesis of bicyclic ketone because this structural unit is the main function of various natural tragments. It is a versatile intermediate in the synthesis of various steroids and hormones. $\Lambda$ tandem reaction comprising a Michael addition step followed by an aldol condensation to produce a cyclic compound is Robinson annulation ${ }^{4.9}$. It is an useful method for the synthesis of natural products consisting of fused ring systems such as terpenes and alkaloids ${ }^{10}$. Robinson annulation can be performed under catalytic conditions using $\mathrm{La}(\mathrm{OiPr})_{3}-\mathrm{MS} 4 \mathrm{~A}^{\mathrm{ll}}$, $\mathrm{Al}_{2} \mathrm{O}_{3}{ }^{12}$, S-proline $e^{13}$, and $\mathrm{AB} 38 \mathrm{C} 2^{14}$. Moreover, solvent-free Robinson annulation with sodium ethoxide ${ }^{15}$ was also performed. It can also be effected in onepot using acid catalysts ${ }^{15.17}$. In this paper, we report synthesis of some 5,7-diaryl-3,4,6-trilydronaphthalen-2-ones.

\section{RESULTS AND DISCUSSION}

Some $\quad 5,7$-diaryl-3,4,6-trilyydronaphthalen-2-ones were synthesized from 3,5-diarylcyclohex-2-en-1ones and methyl vinyl ketone in the presence of sodium ethoxide. The products were characterized on the basis of their IR, UV-visible, ${ }^{1} \mathrm{H} N \mathrm{NMR}$, ${ }^{12} \mathrm{C}$ NMR and Mass spectral studies. To contirm the ${ }^{1} \mathrm{H}$ 


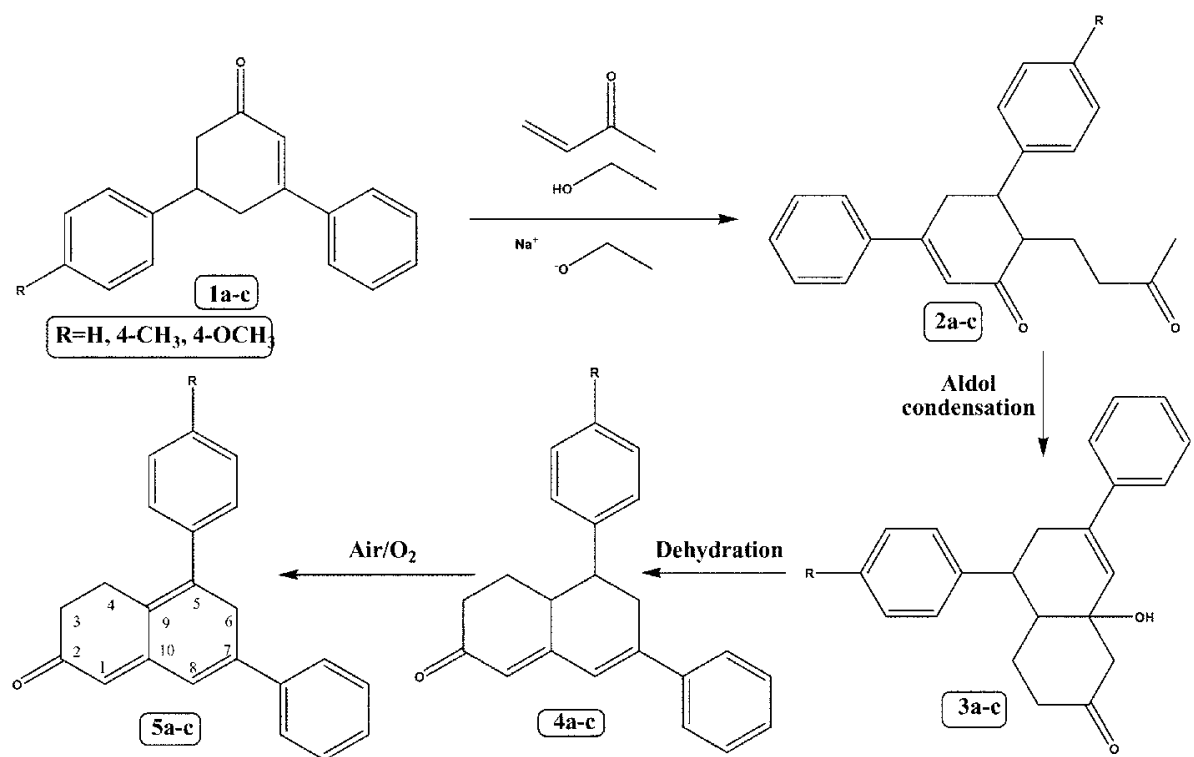

Sorente 1. Sy nuthesis of some 5,7-dianyl-3,4,6-trihydrondphthalen-2-ones.

and ${ }^{13} \mathrm{C}$ NMR spectral assignments, IISQC spectrum was recorded for $\mathbf{5 a}$ and analyzed. Nll the spectral studies along with TLC indication bear evidence that the formed products are $\mathbf{5 a - c}$. The compounds were isolated by column chromatography using petroleum ether-benzene (1:4) mixture as an eluent system. Attempts to isolate $\mathbf{3 a - c}$ and $\mathbf{4 a - c}$ were unsuccessful. The schematic representation describing the route of synthesis is furnished in Scheme 1 .

The IR-spectrum of 5 a showed one strong carbonyl absorption at $1638 \mathrm{~cm}^{-1}$ assignable to a cyclic $\alpha, \beta$-unsaturated ketone stretching trequency. The IR spectrum of la showed carbonyl absorption at $1653 \mathrm{~cm}^{-1}$. $5 \mathbf{a}$ is also a $\alpha, \beta$-unsaturated ketone but it has a frequency of $1638 \mathrm{~cm}^{-1}$, which is lower than the stretching frequency of $\mathbf{1} \mathbf{a}_{4}$ is due to extended conjugation.

In the GC-MS spectrum of $\mathbf{5 a}$, the observed single peak confirms its formation as a sole product. In the mass spectrum the molecular ion peak observed at 298 is also an additional evidence for the formation of $5 \mathbf{a}$. The other important tragment peaks are $270,229,144,116,115,91,76$ and 54 , which agree with the fragment pattern of 2-naphthol. The plausi- ble fragmentation pattern is given in Chart 1.

The UV-visible spectrum of $\mathbf{5}$ a shows two major absorptions at $248 \mathrm{~mm}$ and $288 \mathrm{~nm}$. The $\lambda_{\max }$ at 248 $\mathrm{nm}$ is due to $\pi-\pi *$ transition of phenyl substituent. The other $\lambda_{\text {max }}$ at 288 nm may be due to the unsaturated ketone. The calculated $\lambda_{\max }$ value $297 \mathrm{~nm}$ is almost equivalent to the observed $\lambda_{\max }$ value. If the compound $5 \mathrm{a}$ is a saturated one, then the $\lambda_{\max }$ value should be around $250 \mathrm{~mm}$. But in the case under study $\lambda_{\max }$ is $288 \mathrm{~nm}$ which is adequate confirmation of the fact that $5 \mathbf{a}$ is unsaturated.

The complete ${ }^{1} \mathrm{II}$ and ${ }^{13} \mathrm{C}$ NMR spectral assignments for the products $\mathbf{5 a - c}$ are given in the experimental section.

\section{Analysis of HSQC Spectrum}

To confirm the 'II-NMR and '"C-NMR signals of 5a, HSQC spectrum was recorded and is given in Plate 1. It shows eight cross peaks, which are analyzed as follows: The cross peaks 1 and 2 reveal that the protons are connected to carbon signal at 36 ppm. The signal for the C-4 carbon appears as two signals at 3 and 2.9 ppm. The third cross peak is connected to a carbon signal at 41.5 ppm. C-3 carbon, which appeared at $41.5 \mathrm{ppm}$, is connected 


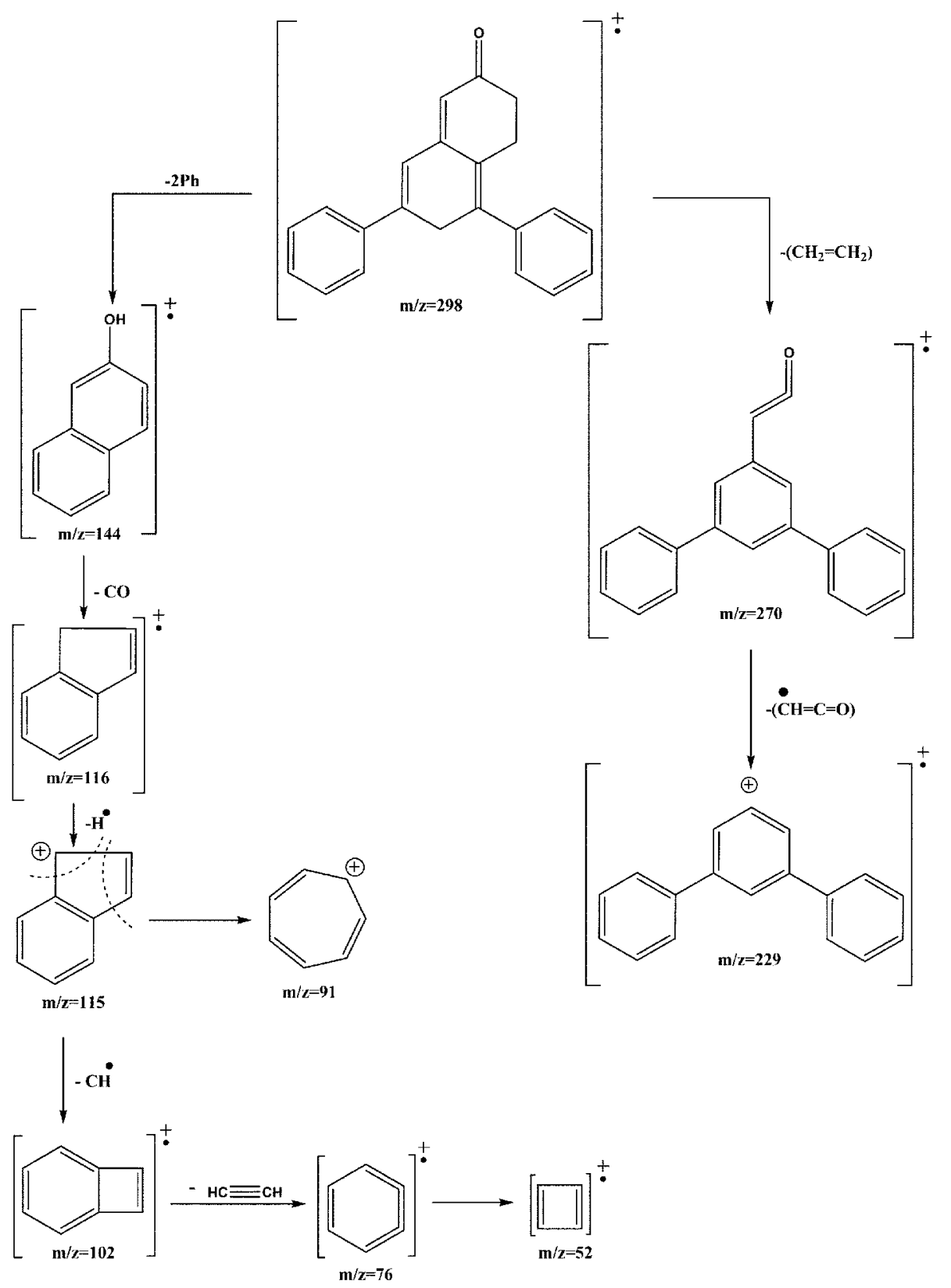

Chart 1. Fragmentation pattern for 5,7-diphenyl-3,4,6-trihydronaphthalen-2-one.

to proton at $3.4 \mathrm{ppm}$. Hence the signal at $3.4 \mathrm{ppm}$ is conveniently assigned to $\mathrm{H}-3$ proton.

The fourth cross peak is connected to a carbon signal at $44.3 \mathrm{ppm}$, which is connected to $\mathrm{C}-6$ carbon and two proton signals at 2.9 and $2.7 \mathrm{ppm}$. IIence the signals at 2.9 and 2.7 ppm are assigned to two $\mathrm{H}-6$ protons.

The fifth cross peak is connected to $7.01 \mathrm{ppm}$ of 'H signal and $113.6 \mathrm{ppm}$ of ${ }^{\text {'s }} \mathrm{C}$ signal. The seventh cross peak is connected to $6.47 \mathrm{ppm}$ of ' $\mathrm{H}$ signal and $125.4 \mathrm{ppm}$ of ${ }^{1} \mathrm{C} \mathrm{C}$ signal. The fifth and seventh cross peaks may be due to $\mathrm{C}-8$ and $\mathrm{C}-1$ carbons and 


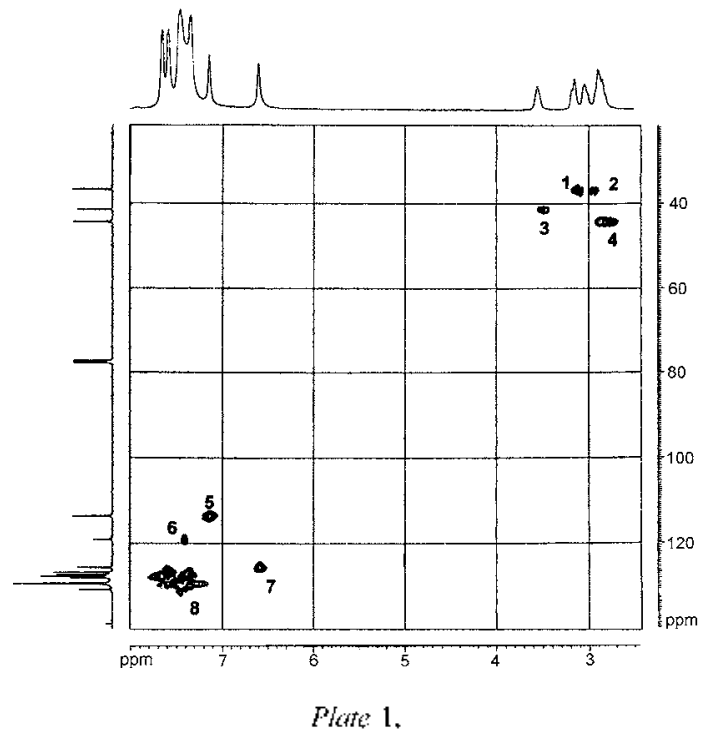

its protons respectively. The proton signals at 7.01 and $6.47 \mathrm{ppm}$ are assigned to II-1 and H- 8 , respectively. The eighth cross peak appears as a cluster that is connecting the carbon signals at aromatic region and its protons.

\section{Experimental Section}

Melting points of the compounds were recorded on an electro-thermal apparatus and are uncorrected. IR-spectra in $\mathrm{KBr}$ were recorded in NICOLET AVATAR-330-FT-IR spectrophotometer. LVvisible spectrum was recorded on HITACHI-L-2001 double beam spectrophotometer. ${ }^{1} \mathrm{H} N \mathrm{MR}$ spectra were recorded on BRLKER $\triangle M \mathrm{MX}-400$ spectrometer operating at $400 \mathrm{MIZ}$. ${ }^{13} \mathrm{C}$ NMR spectra were recorded on BRUKER $\triangle \mathrm{MX}-400$ spectrometer at operating frequency $100 \mathrm{MHz}$. The mass spectra were recorded on VG-MICROMASS-7070F double mass spectrometer. The HSQC was recorded on BRLKER AMX-400 spectrometer. The purity of the compounds was checked on TLC.

The chalcones were prepared according to the literature $^{18}$. 3,5-Diaryl-cyclohex-2-en-1-ones [1a-c] were prepared by adopting the literature procedure ${ }^{14}$.

Preparation of 5.7-Diaryl-3,4,6-trihydronaphthalen-2-one 5a:

$\Lambda$ solution of sodium ethoxide was prepared from
$0.01 \mathrm{~g}$ of freshly cut sodium and $10 \mathrm{ml}$ ethanol in a round-bottomed flask. To this, 3,5-Diphenylcyclohex-2-en-1-one $(0.248 \mathrm{~g}) 1 \mathrm{a}$ in absolute ethanol $(20 \mathrm{ml})$ was added and stirred for one hour at room temperature. To this mixture methyl vinyl ketone $(0.1 \mathrm{ml})$ in absolute alcohol $(10 \mathrm{ml})$ was added and the stirring was continued for over night. To the reaction mixture, $100 \mathrm{ml}$ of $\mathrm{CIICl}_{3}$ followed by ice water were added. The organic phase was separated, washed with brine and dried over anhydrous sodium sulphate. The residue, obtained atter evaporation of the solvent was subjected to column chromatography using petroleum ether-benzene (1:4) as an eluent mixture to afford 5a. Yield: $55 \%$; m.p. 96$98^{\circ} \mathrm{C}$ : MS: $\mathrm{C}_{22} \mathrm{H}_{18} \mathrm{O} ; \mathrm{m} / \mathrm{z}: 298\left(\mathrm{M}^{-\circ}\right), 270,229,144$. $116,115,102,91,76,52 ; \mathbb{R} \mathrm{cm}^{-1}: 3052,1638,1590$. $1573,1495,1446,761,697 ; \mathrm{UV}$ nm: 248,$288 ;{ }^{1} \mathrm{H}$ NMR, $\mathrm{CDCl}_{3}, 8$ ppm: $2.60-2.78(\mathrm{~m}, 2 \mathrm{H}, \mathrm{H}) ; 2.83-2.91$ (m, $1 \mathrm{H}, \mathrm{H}_{43}$ ); 3.01 (dd, $\left.1 \mathrm{H}, \mathrm{H}_{4 \mathrm{c}}\right) ; 3.36-3.44(\mathrm{~m}, 2 \mathrm{H}$, $\left.\mathrm{II}_{3}\right) ; 6.47\left(\mathrm{~s}, 1 \mathrm{II}, \mathrm{II}_{1}\right) ; 7.01\left(\mathrm{~s}, 1 \mathrm{II}, \mathrm{II} \mathrm{f}_{8}\right) ; 7.21-7.56(\mathrm{~m}$, 10II, $\Delta \mathrm{r}-\mathrm{II} \mathrm{s}) ;{ }^{13} \mathrm{C}-\mathrm{NMR}, \mathrm{CDCl} \mathrm{s}_{3} \delta \mathrm{ppm}: 200.2$ (C-2); 159.7 (C-7); 157.2 (C-5); 113.6 (C-8); 125.4 (C-1); 44.3 (C-6); 41.5 (C-3); 36.7 (C-4); 138.7-143.7 (C-9. $\mathrm{C}-10$ and two ipso carbons); $125.4-130.7 \mathrm{Nr}-\mathrm{C}^{\prime} \mathrm{s}$.

Compounds $\mathbf{5 b}$ and $\mathbf{5} \boldsymbol{c}$ were synthesized similarly.

5-(4'-Methylphenyl)-7-pheny-3,4,6-trihydronaphthalen-2-one 5b:

Yield: $50 \%$; m.p.: $102-104^{\circ} \mathrm{C}$; MS: $\mathrm{C}_{23} \mathrm{H}_{210} \mathrm{O}$; $\mathrm{m} / \mathrm{Z}$ : 312 (M०) $^{\circ}, 284,243,144,116,115,102,91,76,52$; $\mathrm{RR} \mathrm{cm}^{-1}: 3050,2973,1630,1585,1570,1490,1440$, $1375,756,693 ;{ }^{1} \mathrm{II}$ NMR, $\mathrm{CDCl}_{3}$, \& ppm: 2.62-2.88 (m, $\left.2 \mathrm{II}, \mathrm{II}_{6}\right), 3.02\left(\mathrm{dd}, 1 \mathrm{HI}, \mathrm{II}_{4 \mathrm{c}}\right), 2.86-2.99(\mathrm{~m}, 2 \mathrm{II}$, $\left.\mathrm{II}_{43}\right), 3.38-3.49\left(\mathrm{~m}_{3} 2 \mathrm{II}_{\mathrm{I}} \mathrm{II}\right), 2.40\left(\mathrm{~s}, 3 \mathrm{II}_{3} \mathrm{CHI}_{3}\right.$ at phenyl ring), 6.52 (s, 1II, II $), 7.08$ ( $\left(\mathrm{s}, 1 \mathrm{IL}, \mathrm{II}_{8}\right) ; 7.60-7.24$ (m, 10II, $\mathrm{Ar}-\mathrm{II} \mathrm{s}) ;{ }^{\prime} \mathrm{C} \mathrm{C} \mathrm{NMR} \mathrm{CDCl}_{3} \delta \mathrm{ppm}: 124.5$ (C-1); 201.4 (C-2); 42.1 (C-3); 37.3 (C-4); 160.3 (C-5); $44.5(\mathrm{C}-6) ; 157.8(\mathrm{C}-7) ; 114.1(\mathrm{C}-8) ; 21.5\left(\mathrm{CH}_{3}\right.$ at Phenyl ring); $137.6\left(\mathrm{C}^{-} \mathrm{CH}_{3}\right) ; 139.2-144.2$ (C-9, C-10 and two ipso carbons); 129.7-125.9 (Ar-C's).

5-(4-Methoxypheny)-7-pheny-3,4,6-trihydronaphthalen-2-one 5c:

Yield: $52 \%$; m.p.: 106-108 ${ }^{\circ} \mathrm{C}$; MS: $\mathrm{C}_{23} \mathrm{H}_{20} \mathrm{O}_{2}$; m/z: $328\left(\mathrm{M}^{\circ}\right), 300,259,144,116,115,102,91,76,52$.; R $\mathrm{cm}^{-1}: 3042,1632,1587,1572,1492,1446,1265$. 
$1248,759,695 ;{ }^{1} \mathrm{H} \mathrm{NMR} \mathrm{CDCl}_{3} \delta \mathrm{ppm}: 2.55-2.72$ (m, $\left.2 \mathrm{H}, \mathrm{H}_{6}\right), 2.78-2.85\left(\mathrm{~m}, 2 \mathrm{H}, \mathrm{H}_{+3}\right), 2.97(\mathrm{dd}, 1 \mathrm{H}$, $\left.\mathrm{H}_{+2}\right), 3.31-3.38\left(\mathrm{~m}, 2 \mathrm{H}, \mathrm{H}_{3}\right), 3.95\left(\mathrm{~s}, 3 \mathrm{H}, \mathrm{OCH}_{3}\right.$ at phenyl ring); $6.41(\mathrm{~s}, 1 \mathrm{H}, \mathrm{H}-1), 7.12\left(\mathrm{~s}, 1 \mathrm{H}, \mathrm{H}_{s}\right)$ 7.10-7.56 (m, 9H, Ar-H's); ${ }^{13} \mathrm{C} \mathrm{NMR} \mathrm{CDCl}, \delta \mathrm{ppm}$ : 200.9 (C-2); $124.7(\mathrm{C}-1) ; 41.0(\mathrm{C}-3) ; 36.2$ (C-4): 159.3 (C-5); 43.9 (C-6); $55.4(\mathrm{OCH}$, at phenyl ring); 156.7 (C-7); $113.9(\mathrm{C}-8) ; 143.1-138.1$ (C-9, C-10 and two ipso cartons); 159.2 (C-OCII $)$ ); 124.9-128.9 (Ar-C"s).

Acknowledgement. We wish to thank NMR Research Centre, (Sophisticated Instruments Facility), ISc, Bangalore, India for recording $\mathrm{MMR}$ spectra.

\section{REFERENCES}

1. Michael, J. J. Perakt, Chem. 1887, 35, 251.

2. Koller, A. An. Chem. J. 1907, 37,385.

3. Vorlander, S. Ann. 1902, 66, 320.

4. Du Feu, E. C.; Mc Quillin, F. J.; Robinson, R. J. Chem. Soc: 1937,53 .

5. Balasubramanian, K.: John, J. P.; Swaninathan, S. Synthesis 1974, 51.

6. Bergmann, E. D.; Gingberg, D.: Pappo, R. Org. React. $1959,10,179$.

7. Trost, B. M.: Fleming, 1. Comprehentsive Organic Syn- thesis: Selectivity, Strategy and Efficiency in Modern Organic Chemistry, Pergamonn Press, New York; 1991. $2,4$.

8. Rapson, W. S.; Robinson, R. J. Chem. Soc. 1935, 1285.

9. Ramachandran, S.; Newmann, M. S. Orgonic Sy whesis. Joln Wiley and Sons, Jnc; NewYork, 1973, $5,486$.

10. Ho, L.C. Carboxicle Constntion in Terpene Sinthesis. VCH Publishers Inc; NewYork, 1988.

11. Okano, T.: Satou, Y:: Tamura, M.: Kịi, J. Bull. Chent. Sor. Jpn. 1997, 70, 1879.

12. Takatori, K.: Nakayama, M.: Yamada, N.: Hirayam, \$.: Kasiward, M. Chent. Pham. Bull. 2003, $4,455$.

13. Rajagopal, D.: Narayanan, R.: Swaminathan, S. Proc. Indian Acad. Sci. (Chent. Sci.l. 2001, 113, 197.

14. Zhong, G: Hoftmann, T.: Lerner, R. A.: Danishefsky, S.: Barbas, C. F. J. Ant Chem. Soc. 1997, J19, 8131 .

15. Miyamoto, H.: Kanetala, S.: Tanaka, K.: Yoshizawa: Toyota, S.: Toda, F. Chent Lett. $2000,888$.

16. Heathoock, C. H.; Ellis, J. E.; Mc Murry; Cappolino, A. Tetrahedron Lett. 1971, J2, 4995.

17. Headicock, C. H.; Mahaim, C.; Schleclit, M. F.; Utawanit, T. J. Org. Chem. 1984, 49, 3264.

18. Furniss, B. S.; Hannaford, A. J.; Smith, P. G; Tatchell, A. R. Vogel's textbook of practical organic chemistry" $5^{\text {;it }}$ ed. ELBS, 1997, 1033.

19. Balasubramanian, M.; Souza, A. D. Tetrahedron. 1968. 24. 5399 . 